\title{
MOTIF DAN STRATEGI GERAKAN FILANTROPI MUHAMMADIYAH
}

\section{- Hafidz Arfandi}

Universitas Gadjah Mada (UGM) Yogyakarta, Indonesia

Email: hafidzarfandi@gmail.com

\begin{abstract}
Abstrak
Penelitian ini akan menyoroti gerakan kesejahteraan sektor ketiga yang lahir dari komunitas muslim di Indonesia, yaitu Muhammadiyah. Selama ini, filantropi pada Muhammadiyah seringkali disalahpahami hanya terkait dengan lembaga amil, zakat, infaq dan shadaqah yang menjadi bagian kecil dari sistem Muhammadiyah. Pandangan tersebut terlalu terburu-buru dan membuktikan kegagalan sebagian besar orang melihat konsep filantropi secara luas dan mereduksinya. Riset ini menggunakan studi kasus peggalian data secara historis dengan menggunakan pendekatan teori motif dari tradisi kedermawanan (gift).
\end{abstract}

Kata Kunci: Muhammadiyah, Negara, Filantropi, dan Pelayanan Sosial 


\section{Pendahuluan}

Negara memiliki keterbatasan sebagai penyedia layanan kesejahteraan bagi masyarakat. Hal ini sangat ditentukan oleh faktor finansial dan birokrasi dalam merespons kebutuhan aktual. Ketidakmampuan negara dalam merespons tuntutan publik pada akhirnya melahirkan ketidakpercayaan, sehingga membuka peluang pada lahirnya instabilitas. ${ }^{1}$ Ketika krisis terjadi, yang muncul bukan usaha kolektif masyarakat untuk berbagi, tetapi justru kepelitan sosial yang akan mengekslusi.

Hingga saat ini, Indonesia belum dapat dikatakan mampu menerapkan welfare state yang mapan. Meski begitu, negara ini sedang berusaha membangun legitimasinya dengan memberikan layanan kesejahteraan kepada masyarakat. Hal ini bersamaan dengan pembangunan yang sedang berjalan. Persoalannya, upaya ini menghadapi dilema karena pemerintah tidak memiliki cukup finansial. Indonesia dihadapkan pada problematika pelik dengan tingginya angka kemiskinan dan sejumlah masalah sosial.

Di negeri ini, potensi penopang kesejahteraan yang tidak bisa dinafikan eksistensinya adalah filantropi. Gerakan filantropi yang muncul saat ini ditandai dengan keberadaan berbagai lembaga swadaya masyarakat yang mengandalkan pendanaan dari masyarakat untuk pelayanan sosial, baik di tingkat lokal maupun internasional.

Dalam hal ini, filantropi terbagi menjadi dua tipologi; (1) Filantropi yang berasal dari tradisi kedermawanan (giving) sebagaimana yang diajarkan dalam doktrin agama. (2) Filantropi sekuler yang muncul sebagai respons terhadap industrialisasi yang melahirkan kelompok menengah baru yang peduli terhadap kaum miskin. ${ }^{2}$ Filantropi berusaha menggalang kepedulian dan keterlibatan masyarakat untuk mengalokasikan pendanaan dalam rangka berkontribusi bagi aktivisme sosial. Salah satu filantropi yang paling berpengaruh dan paling potensial di Indonesia adalah filantropi Islam. ${ }^{3}$

Penelitian ini menyoroti gerakan kesejahteraan sektor ketiga yang lahir dari komunitas muslim di Indonesia, yaitu Muhammadiyah. Gerakan filantropi di Persyarikatan seringkali disalahpahami hanya terkait dengan lembaga amil,

1 Ife, Jim, dan Frank Tesoriero, Community Development: Alternatif Pengembangan Masyarakat di Era Global, (Pustaka Pelajar: Yogyakarta, 2008).

2 James Midgley, Social Welfare in Global Context (London: Sage Publication, 1997).

3 Vandendael, Anoux, et al, Stimulating Civil Society The Perspective of INGO: an Explorative Study of Indonesia (Erasmus University, 2013). 
zakat, infaq dan shadaqah yang hanya menjadi bagian kecil dari sistem organisasi Muhammadiyah. Di sisi lain, studi tentang filantropi di Muhammadiyah juga belum banyak diulas. ${ }^{4}$

Studi ini ingin memotret Muhamamdiyah dalam rangka melihat tipologi gerakan filantropi. Filantropi sudah sangat kentara dan identik dengan gerakan Muhamamadiyah. Sebagai organisasi sipil, Muhammadiyah memiliki tujuan dan capaian yang beragam dengan struktur organisasi yang kompleks dan berjejaring luas. Hal ini menunjukkan perbedaan dengan organisasi filantropi Islam lain yang seringkali hanya dikaitkan dengan lembaga amil zakat.

Di balik bentuk struktur organisasinya, Muhammadiyah tidak dapat dilepaskan dalam konteks relasi sosial dan politik. Sejak awal, Muhammadiyah bekerja sebagai pengelola sumber daya publik melalui aktivisme sosial, baik yang berbasis pelayanan, pemberdayaan maupun pemberian aset untuk usaha peningkatkan kualitas kesejahteraan kaum marjinal. Studi ini fokus pada dua hal: Pertama, bagaimana motif kelahiran Muhammadiyah sebagai gerakan filantropi Islam. Kedua, melihat konteks relasi sosial-politik di balik lahirnya kebijakan filantropi Muhammadiyah dari masa ke masa.

Artikel ini menggunakan metode penggalian sejarah dengan menggunakan pendekatan teori motif dari tradisi gift yang diperkenalkan Alan Page Fiske yang menyebut motif gift terdiri dari empat tipe; authority ranking, community sharing, market pricing dan equality matching. Selain itu, studi ini berusaha melihat teori relasi sektor informal (voluntary sector) dan sektor formal (negara) meminjam teori Helmke dan Levitsky yang membagi tipologi relasi berdasarkan kriteria kesamaan atau perbedaan tujuan sektor formal dan informal, serta efektifitas negara.

Teori ini ditempatkan untuk memotret mengenai pelayanan Muhammadiyah dalam konteks sosial politik yang dinamis dari berbagai fase pemerintahan. Helmke dan Levitsky melahirkan empat tipologi relasi yaitu: akomodatif, kompetisi, komplementer, dan substitusi. ${ }^{5}$

4 Hanya beberapa tulisan yang membahas filantropi di Muhammadiyah, di antaranya Hilman Latif, Melayani Umat: Filantropi Islam dan Ideologi Kesejahteraan Kaum Modernis (Jakarta: Maarif Institut dan Kompas Gramedia, 2010). Lihat juga Amelia Fauzia, Faith and State: A history Islamic Philanthropy in Indonesia (Leiden: Brill, 2013). Riset Amelia meneliti perkembangan filantropi Islam di Indonesia dan salah satunya adalah yang dilakukan Muhammadiyah, khususnya di era kolonial dan Orde Baru.

5 Gretchen Helmke dan Steven Levitsky, Informal Institution and Comparative Politics: A Research Agenda, Kellog Institute, Working Paper \#307, September 2003. 


\section{Bukan sekedar Derma}

Filantropi seringkali hanya dimaknai sebagai proses amal (charity). Menurut Helmut K. Anheier dan Regina. A. List, antara charity dan filantropi berbeda dari sisi tujuan pemberiannya, charitas dimaksudkan sekedar memberikan untuk kebutuhan jangka pendek, sedangkan filantropi berupaya untuk menyelidiki dan menyelesaikan sebab utama dari persoalan. Beberapa studi menunjukkan bahwa konsep filantropi lebih diarahkan pada model filantropi untuk keadilan sosial yang mendorong bukan hanya reaktif terhadap masalah di depan mata, melainkan memerlukan kemampuan untuk mereproduksi lahirnya struktur sosial, ekonomi dan politik yang lebih menguntungkan mereka yang tidak mampu secara ekonomi. ${ }^{6}$

Dalam tradisi Islam, pemahaman filantropi telah berakar kuat melalui adanya perintah zakat, infaq, shadaqah dan waqaf (Ziswaf). Zakat merupakan konsep tunggal dalam Islam yang menuntut kewajiban setiap muslim untuk menyisihkan sebagian hartanya yang sudah memenuhi kriteria jumlah dan waktu tertentu berdasarkan ketentuan khusus. Sedangkan infaq, shadaqah dan waqaf lebih merupakan pilihan yang tidak diwajibkan, melainkan disunahkan dalam rangka kepentingan umum. Zakat dari sisi penerimanya juga sudah memiliki kriteria tersendiri yaitu 8 golongan yang disebutkan dalam al-Qur'an maupun al-Hadist. Berbeda dengan zakat, konsep infaq, shadaqah dan waqaf lebih memiliki keluasan bagi penerima manfaatnya hanya saja memang lebih ditekankan untuk memenuhi kebutuhan umum serta melayani mereka yang tidak mampu.

Gregory C. Kozlowski menyebutkan, zakat sebenarnya bukan filantropi yang bermakna belas kasihan pada manusia lain serta upaya redistribusi aset, melainkan sebuah kewajiban agama yang dilakukan karena keinginan untuk mendekatkan diri dengan Tuhan. ${ }^{7}$ Konsep ini secara tekstual memang benar, sebaliknya secara kontekstual zakat tidak bisa semata-mata ditempatkan dalam ruang kosong secara sosial. Zakat selalu terkait dengan pilihan-pilihan rasional seseorang untuk memberikan pada siapa dan melalui apa dan berapa banyak. Hal ini dikarenakan tidak ada kewajiban mutlak tentang bagaimana proses pemberian zakat sehingga proses pemberian itu tidak mungkin dilepaskan dari relasi yang kontekstual.

6 J. Hunsaker dan B. Hanzl, "Memahami Filantropi Keadilan Sosial" dalam Jurnal Galang, Vol. 1, No. 1, (Oktober, 2003).

7 Gregory C. Kozlowski, "Otoritas Agama, Reformasi dan Filantropi di Dunia Islam Kontemporer," dalam Ilchman, E Warren, et. al., Filantropi di Berbagai Tradisi Dunia (Jakarta: Center of the Study of Religion and Culture, 2006). 
Di Indonesia, pengelolaan zakat telah menjadi tradisi di lingkungan umat Islam. Negara tidak pernah ikut campur tangan dalam pengelolaan zakat. ${ }^{8}$ Zakat biasanya diberikan masyarakat kepada institusi agama di sekitarnya, mulai dari pengajian, pesantren, sekolah agama, yayasan atau organisasi Islam, atau pada seorang ulama setempat. ${ }^{9}$

\section{Filantropi Muhammadiyah}

Pada dasarnya, filantropi Islam merupakan reinterpretasi dari ajaran agama yang menganjurkan derma. Selama ini, aktualisasi dari ajaran ini diterapkan dengan beragam metode, baik dilakukan secara indvidu maupun kolektif berdasarkan pada konteks budaya masyarakatnya. ${ }^{10}$ Persentuhan antara filantropi tradisional dan modern mulai membentuk sebuah gerakan baru. Gerakan ini berorientasi menjadikan filantropi sebagai alat untuk mengentaskan masalah sosial.

Hadirnya lembaga filantropi Islam di Indonesia menunjukkan adanya reorientasi menuju model filantropi modern. Institusionalisasi filantropi Islam di Indonesia muncul sebagai bentuk transisi antara bentuk-bentuk traditional giving menuju mobilisasi yang berkelanjutan pada sumber daya yang indigeneous.

Konteks di Indonesia, solidaritas sosial filantropi Islam terwujud dalam wujud kemunculan sejumlah lembaga sektor ketiga yang dibangun atas inisiatif masyarakat. Hilman Latief menyebutkan, inisiatif masyarakat untuk melakukan pengorganisasian diri telah dilakukan melalui berbagai cara di antaranya dengan mendirikan lembaga sosial, baik yang bergerak di bidang pendidikan, kesehatan dan pelayanan sosial. Keberadaannya tidak hanya memberi nafas dan darah baru bagi masyarakat untuk terlibat dalam pembangunan di luar struktur pemerintah, tetapi juga menjadi alternatif ketika kebutuhan masyarakat lebih besar daripada

Lihat dalam Ridwan Al Makassary, "Pengarus Utamaan Filantropi Islam untuk Keadilan Sosial di Indonesia: Proyek yang Belum Selesai," Jurnal Galang, Vol. 1, No. 3, (April 2006).

9 Dinamika akar rumput ini berjalan dalam tradisi masyarakat Indonesia, terkadang zakat juga tidak dimaknai sebagaimana mestinya (dihitung dan memenuhi ketentuan khusus). Tradisi zakat pada masyarakat Indonesia lebih identik dengan sedekah, tetapi dimaknai sebagai zakat. Survei PIRAC pada 2000-2004 di 10 kota besar, menemukan rata-rata masyarakat Indonesia di kota-kota besar membayar zakat sekitar Rp124 ribu. Riset yang dilakukan Baznas dan IPB dan IDB menunjukan potensi zakat masyarakat Indonesia sebesar Rp217 trilyun, meski yang tercatat oleh Baznas pada 2012 baru sebesar Rp2,2 trilliyun (1\% dari total potensinya). Lihat selengkapnya dalam http:// bimasislam.kemenag.go.id/informasi/berita/35-berita/706-menag-terima-laporan-perkemba-ngan-zakatdari-baznas.html diakses pada 20 november 2013, pukul 17.06.

10 Hilman Latief, Politik Filantropi Islam di Indonesia: Negara, Pasar dan Masyarakat Sipil (Yogyakarta: Ombak, 2013). 
kapasitas yang dimiliki pemerintah. Dalam hal ini, Muhammadiyah tidak bisa dilepaskan dalam konteks sosial tersebut.

Pendiri Muhammadiyah, KH. Ahmad Dahlan membentuk organisasi ini sebagai gerakan multisektoral yang bersifat ortodoksi dan otopraksi. Muhammadiyah berusaha melakukan pemurnian agama sekaligus juga melakukan aksi pembaharuan. Muhammadiyah membentuk berbagai majelis yang spesifik untuk menangani berbagai permasalahan umat. Pilihan ini tidak lepas dari rasionalisasi konteks sosial politik yang melatar belakangi kelahirannya. Muhammadiyah muncul tidak sekedar sebagai gerakan dakwah Islam, melainkan berusaha untuk membangun fondasi gerakan pembaharuannya secara komprehensif melalui berbagai program sosial.

Pembaharuan Muhammadiyah salah satunya dilakukan dengan mendorong perubahan kultural tentang pembayaran zakat. Muhammadiyah mendorong pengumpulan zakat untuk disalurkan kepada fakir miskin. Padahal sebelumnya zakat dibayarkan pada para tokoh agama setempat dan dijadikan pendapatan bagi mereka. ${ }^{11}$ Dorongan untuk berzakat memunculkan semangat pada anggotanya untuk berderma, tenaga bahkan mewakafkan kelebihan aset berupa tanah atau rumah untuk mendirikan berbagai fasilitas pelayanan Muhammadiyah di daerahnya masing-masing. Pada awal-awal pendirian Muhammadiyah, hampir semua fasilitas yang didirikan adalah dukungan penuh dari anggotanya. Alfan Alfian mencatat, bahwa pada periode 1923, pendapatan Muhammadiyah di Jogjakarta sebesar f 64,737.59 dengan komposisi 1\% dari iuran anggota, 37\% dari donasi, $8 \%$ dari zakat, $12,5 \%$ dari subsidi, $13,5 \%$ dari jasa pendidikan dan dari perusahaan $8 \%$. Proporsi dana donasi dan zakat menjadi pos pendapatan terbesar bagi aktivisme Muhamamdiyah. ${ }^{12}$

Gerakan Muhammadiyah mendapat sambutan antusias di kalangan umat Islam khususnya komunitas kelas menengah baik dari kalangan pedagang, pengrajin dan pamong praja. Komposisi anggota Muhammadiyah yang didominasi kelas menengah menjadikannya berkembang di kota-kota utama di Jawa dan Sumatera, seperti Yogyakarta, Pekalongan, Solo, Kudus, Semarang, Cilacap, Malang, Surabaya, Lumajang, Jakarta dan Padang. Deliar Noer menyebutkan bahwa pada 1925, Muhammadiyah telah mempunyai 29 cabang dengan 4000 orang anggota. Pada periode ini, Muhammadiyah sudah mampu membangun

Lihat Mitsuo Nakamura, Bulan Sabit Muncul Dibalik Beringin: Studi tentang Pergerakan Muhammadiyah di Kota Gede (Yogyakarta: Gajah Mada University Press, 1983). 
banyak fasilitas di bidang sosial, pendidikan dan kesehatan, di antaranya 8 HIS, 1 Kweekschool, 32 Standardschool, 14 Madrasah, 2 Klinik, 1 Rumah Miskin dan 2 Rumah Yatim. Pada periode 1937 sudah terbentuk 921 cabang di seluruh Indonesia: Jawa-Madura sebanyak 401 cabang, Sumatera sebanyak 368 cabang, Sulawesi sebanyak 105 cabang, Kalimantan 33 dan lainnya 14 cabang. Pada dekade awal berdirinya keanggotaan Muhammadiyah juga menunjukan pertumbuhan yang sangat pesat. Deliar Noer memperkirakan pada 1921 anggotanya baru mencapai 597 orang dan meningkat pesat pada 1925 sebesar 4000 orang dan pada 1930 menjadi 24000 dan 1935 sudah mencapai 43000 dan 1938 mencapai 250.000 orang. ${ }^{13}$

Eksistensi layanan kesejahteraan berbasis filantropis yang diberikan Muhammadiyah pada masa itu mampu melahirkan pengaruh dan legitimasi sebagai patron bagi kalangan pribumi. Muhammadiyah dianggap masyarakat mampu memberikan alternatif akses kebutuhan akan layanan pendidikan, kesehatan dan sosial bagi kaum pribumi. Layanan ini telah disediakan, namun kebijakan pemerintah memilih mempertahankan stratifikasi sosial menjadikan kebijakan tersebut berorientasi pada pemecahan kelas, sehingga membatasi akses layanan pendidikan yang berkualitas. Pribumi kelas menengah dan rendahan hanya mendapatkan akses sekolah rakyat (volkschool). Dalam konteks ini lahirlah motif authority ranking yang direproduksi dalam layanan kesejahteraan Muhamamdiyah yang berusaha melahirkan garis hirarkis dalam struktur masyarakat malalui pembentukan kuasa, kewibawan, populisme, dan pembuktian-pembuktian prestasinya. ${ }^{14}$ Sikap ini ditujukan untuk memastikan bahwa mereka yang paling atas memiliki otoritas untuk mendorong inisiatif serta memobilisasi sumber daya yang diatasnamakan seluruh bagian dari komunitas masyarakat pribumi.

Patronase dan legitimasi yang diterima masyarakat terhadap Muhammadiyah tidak dijadikan wahana membentuk stratifikasi kuasa baru. Sebaliknya patronase ini muncul seiring dengan lahirnya kewibawaan Muhammadiyah untuk memobilisasi dukungan masyarakat. Egbert Harmsen menyebutkan, pengalaman relasi civil society dan negara di Yordania mammpu melahirkan patronase

12 Alfan Alfian, Politik Kaum Modernis: Perlawanan Muhammadiyah terhadap Kolonialisme Belanda (Jakarta: Al Wasat, 2012), h. 218

13 Baca selengkapnya dalam Deliar Noer, Gerakan Islam Modern di Indonesia: 1990-1942 (Jakarta: LP3ES, 1982).

14 Lihat definisi authority ranking dalam Alan Page Fiske, dalam Aafke Komter, Social Solidarity and the Gift (Cambridge: Cambridge University Press, 2005). 
bertingkat. Pola patronase ini terbentuk justru dengan lahirnya civil society yang dengan sengaja diberikan celah oleh negara untuk tampil. Negara mendapat keuntungan dengan menjadi puncak dari patronase tersebut sedangkan civil society yang lahir cenderung tampil untuk memperkuat legitimasi negara dengan membentuk patronase terbatas di masyarakat.

Perbedaan mencolok antara patronase civil society di Yordania dengan Muhammadiyah pada fase ini adalah inisiatif kemunculannya yang berasal dari masyarakat sebagai reaksi counter atas dikriminasi negara. Sedangkan di Yordania civil society muncul dari insentif yang diberikan negara. Reaksi counter ini menjadikan relasi Muhamamdiyah dan negara semata-mata dalam rangka mempertahankan dukungan atas aktivismenya.

Di sisi lain, Muhammadiyah berusaha secara rapi menyimpan sebuah agenda tersembunyi untuk melawan agenda negara kolonial. Strategi ini diwujudkan dengan upayanya untuk membangun gerakan yang bersifat populis sebagai sarana menarik simpati komunitasnya untuk memberikan dukungan sekaligus bergabung sebagai anggotanya. Dukungan tersebut diartikulasikan Muhammadiyah sebagai representasi sikap pribumi untuk berhadapan dengan negara kolonial. Muhammadiyah berhasil menerobos keterbatasan negara dengan memperkuat pengaruh gerakannya dihadapan kaum pribumi sekaligus dalam waktu bersamaan menarik dukungan negara terhadapnya.

KH. Ahmad Dahlan memandang serius dua persoalan menyangkut kaum pribumi. Pertama, adanya barier dengan kebijakan legal diskriminatif yang dilakukan negara sehingga memaksa mayoritas populasi pribumi muslim tidak mendapatkan layanan pendidikan dan kesehatan yang memadai. ${ }^{15} \mathrm{Kedua}$, adanya potensi ancaman dari masifnya pengaruh gerakan misi Katolik dan Zending Kristen yang dengan dukungan penuh pemerintah mampu menyediakan layanan pendidikan, sosial dan kesehatan.

Aktivisme sosial gerakan misi gereja dianggap sebagai upaya serius untuk menjauhkan masyarakat pribumi terhadap Islam. Hindia Belanda dan gereja melakukan perselingkuhan kepentingan yang berorientasi untuk mengubah

15 Terdapat dua jenis diskriminasi, pertama, legal diskriminasi, yaitu sebuah kehendak sadar yang dilakukan negara untuk meminggirkan suatu kelompok dari akses-akses dan fasilitas sosial, ekonomi dan politik yang tercermin dalam sebuah legal formal (hukum), Kedua, sosial diskriminasi, yaitu, munculnya status warga kelas dua yang terpinggirkan akibat adanya perbedaan terhadap akses sosial, politik dan ekonomi, tidak tercermin dalam hukum formal tetapi menjadi rasionalisasi kebijakan, lihat Dixon, John dan Robert P. Scheurrel (ed.), Social Welfare in Indigenous People (London: Routledge, 1995), h. ix. 
struktur dan kultur masyarakat Hindia. Upaya negara dan sekaligus gerakan gereja untuk melakukan layanan sosial bagi pribumi tidak lain menciptakan legitimasi dan penanaman pengaruh sosial di kalangan pribumi untuk menciptakan masyarakat pribumi baru yang pro Hindia Belanda. Upaya ini dinilai berpotensi meruntuhkan legitimasi tradisional utamanya kalangan para santri muslim. Vanderbosh mencatat, terjadi peningkatan 40\% fasilitas pendidikan gerakan misi akibat adanya dukungan finansial pemerintah sejak 1909-1912. Hal ini mendorong peningkatan partisipasi pribumi sebesar 20\% di sekolah-sekolah swasta milik gerakan misi.

Muhammadiyah berusaha menghadapi gerakan misi gereja dengan membangun fasilitas tandingan untuk bersaing memperebutkan pengaruh di kalangan pribumi. Perebutan pengaruh ini pada dasarnya berusaha menunjukan spirit bahwa kaum pribumi mampu maju dengan upaya kolektifnya sehingga tidak mudah terpengaruh oleh berbagai pemberian komunitas gereja yang didukung oleh negara. Sikap ini terwujud dalam diri KH. Ahmad Dahlan yang selalu menyerukan perlunya pembaruan sikap di kalangan komunitas muslim untuk bisa menerima kemajuan dan mengambil spirit sosial yang terkandung dalam Surat Al-Maun. ${ }^{16} \mathrm{KH}$. Ahmad Dahlan menafsirkan surat Al Ma'un sebagai keharusan untuk mewujudkan pelayanan sosial. Menolong kaum dhuafa melalui gerakan amal shaleh yang nyata secara sosial. Beliau memandang pentingnya umat Islam untuk saling tolong menolong sesamanya. Lahirnya kolektifitas dan solidaritas umat diharapkan mampu memberikan kekuatan untuk meraih posisi yang setara dengan kelas pribumi dan bangsa Eropa.

Perebutan legitimasi di tengah kebijakan diskriminatif sekaligus rasa apriori kepada netralitas kekuasaan melahirkan kecenderungan membentuk perjuangan politik identitas kaum pribumi. Syafi'i Ma'arif menjelaskan, politik identitas dikaitkan dengan kepentingan anggota-anggota sebuah kelompok sosial yang merasa diperas dan tersingkir oleh dominasi arus besar dalam sebuah bangsa atau negara. ${ }^{17}$ Politik identitas selalu identik dengan lahirnya pandangan entonasionalisme, dalam kaitannya dengan Muhammadiyah ia muncul dari perasaan

16 Surat ke 107 dalam Al Qur'an isinya: “Tahukah kamu siapa pendusta agama? Mereka itu orang yang menghardik anak yatim, dan mereka yang tidak menganjurkan memberi pada orang miskin, dan celakalah orang yang lalai dalam shalatnya, yaitu orang yang ria dan enggan member bantuan.”

17 Syafi'i Ma'arif, Politik Identitas dan Masa Depan Pluralisme Kita (Jakarta: Democracy Project dan Yayasan Abad Demokrasi, 2012). 
ingin bebas dari kolonialisme yang dianggap sekuler ataupun dekat dengan gereja dan membentuk sebuah masyarakat baru Hindia yang religius dan berkemajuan.

Persaingan antara Muhammadiyah dengan gerakan misi dan Zending lahir secara simultan akibat kebijakan negara. Gerakan misi dan Zending tumbuh dari subsidi dan pemberian otoritas yang besar dari negara. Sedangkan, Muhammadiyah lahir sebagai reaksi atas kebijakan negara yang dianggap diskriminatif. Situasi ini menciptakan kondisi di mana Muhammadiyah tidak secara langsung berhadap-hadapan dengan negara. Pada dasarnya, negara memiliki kemampuan yang cukup untuk menciptakan usaha penyediaan layanan. Hanya saja rasionalisasi kebijakan yang dimilikinya menjadi penghambat. Hambatan ini menjadikan kehadiran negara cenderung tidak efektif untuk menyediakan layanan kesejahteraan.

Keberadaan amal usaha Muhammadiyah di berbagai bidang tidak terlepas dari visi organisasi yang pro pembaharuan, tapi antikolonialisme. Di bidang pengajaran, pembentukan sekolah tidak semata-mata untuk bersaing dengan sekolah negeri yang didirikan pemerintah Kolonial ataupun sekolah misi swasta yang dilahirkan gerakan misi, melainkan ada maksud penanaman visi pembaharuan agama Islam sekaligus penanaman nilai-nilai kebangsaan.

Mitsuo menyebutkan, sekolah Muhammadiyah menghasilkan banyak kader yang bisa baca tulis, nasionalis fundamental, punya keyakinan agama, menyesuaikan dengan kondisi ekonomi modern dan terdidik dalam kegiatan organisasi secara sembunyi-sembunyi pada akhir 1930-an. Modernisasi sekolah yang dilakukan Muhammadiyah dengan mencampur pelajaran umum dan agama, serta bahasa. Sekolah Muhammadiyah mengajarkan bahasa Melayu (bahasa Indonesia), Arab dan Inggris sebagai pelajaran khusus. Selain itu ilmu umum, seperti biologi, matematika, ilmu bumi, dan lain-lain diajarkan dengan satu nilai bahwa pelajaran ini penting untuk membaca ayat-ayat Tuhan. ${ }^{18}$ Keunggulan lain sekolah Muhammadiyah adalah keterbukaan aksesnya untuk semua kalangan, tidak seperti sekolah negeri yang masih sulit menerima murid di luar anak bangsawan dan pegawai pemerintah.

Dinamika sekolah muhammadiyah memadukan antara kecakapan pergaulan dengan pengenalan bahasa untuk pergaulan dengan berbagai kelas sosial sekaligus modifikasi pengajaran dengan memberikan pelajaran Ilmu non agama sebagai bentuk reinterpretasi tentang tuntutan ajaran agama untuk memahami hakikat dari sunatullah -hukum tuhan dalam alam semesta-, selengkapnya Lihat Nakamura Mitsuo, Bulan Sabit Muncul Dibalik Beringin: Studi tentang Pergerakan Muhammadiyah di Kota Gede (Yogyakarta: Gajah Mada, 1983), h. 107-109. 
Misi pembaharuan agama tampak dalam bidang sosial dan kesehatan dengan berdirinya bidang Penolong Kesengsaraan Oemom (PKO). PKO diawali terbentuknya tim penolong untuk menangani korban meletusnya Gunung Kelud (1918). Pada 1921, PKO diakui sebagai bidang khusus di Muhammadiyah. Pada tahun itu, PKO memberikan bantuan pada korban kebakaran di Yogyakarta. Lalu, pada 1922 rumah yatim pertama berdiri. Klinik yang paling pertama dibentuk adalah PKO di Yogyakarta (1921), PKO Kota Gede (1925), disusul kemudian klinik di Solo (1929), Malang (1929) dan Surabaya (1930). Sejumlah klinik ini berdiri dengan tujuan utama untuk menolong orang sakit. Namun ada tujuan lain yang menyertainya, di antaranya; Pertama, menantang model pengobatan tradisional, agar orang yang sakit tidak pergi ke dukun atau melakukan ritual-ritual untuk penyembuhan. Kedua, klinik ini dimaksudkan untuk menandingi keberadaan klinik-klinik yang dibangun oleh misionaris Katolik dan para zending Kristen. Selain membidangi kesehatan PKO juga membidangi urusan sosial lainnya, seperti yatim piatu dan santunan warga miskin. Eksistensi layanan tersebut memperkuat legitimasi Muhammadiyah dihadapan komunitas pribumi.

Tujuan yang tersembunyi di balik layanan Muhammadiyah secara garis besar bisa dilihat dalam dua hal; Pertama, upaya untuk melakukan kritik di internal komunitas, utamanya terkait sikap tradisional yang dianggap bertentangan dengan ajaran agama dan menciptakan keterbelakangan. Kedua, upaya bersaing dengan pihak eksternal yang memiliki tujuan berseberangan, tetapi memiliki cara-cara ampuh yang ditirunya. Muhammadiyah mengembangkan aspirasi yang berbeda dengan tujuan layanan yang diberikan kolonial. Hilman Latief mengatakan, tujuan pelayanan sosial negara kolonial sebatas memenuhi kebutuhan administratif dan mempertahankan stratifikasi sosial di masyarakat Hindia. Sedangkan, Muhammadiyah berupaya memperkuat kaum pinggiran (pribumi non aristokrat) yang tak mendapatkan akses untuk bisa tampil setara.

Bagi pemerintah kolonial Hindia Belanda, sekolah dan rumah sakit pemerintah selalu menjadi alat bagi proses sekulerisasi dan pembaratan kaum pribumi. Sedangkan Muhammadiyah menjadikannya sebagai fasilitas pembentukan semangat etnonasionalisme-religius dan penguatan nilai-nilai agama Islam yang berorientasi pada pembaharuan dan kemajuan.

Muhammadiyah dan misi Gereja menjadi dua aktor di luar negara yang saling bersaing untuk saling memperebutkan legitimasi. Kedua aktor non-state 
yang saling bersaing ini cenderung berusaha mempertahankan hubungan baiknya dengan negara untuk memastikan keduanya didukung, baik secara finansial maupun regulasi politik agar tetap dibiarkan melaksanakan aktivismenya. Posisi ini ditunjukan dengan kedekatan KH. Ahmad Dahlan dan kepiawaiannya dalam menjalin relasi dengan pemerintah kolonial dan pihak misi gereja sekaligus.

Negara dalam kapasitas terbatas cenderung mengapresiasinya reputasi Muhammadiyah dengan mengakui dan mensubsidi fasilitas sosial yang dimilikinya. Pemerintah kolonial memberikan subsidi kepada Muhammadiyah sebesar $f$ 12916,40 untuk PKO dan f 50377,05 untuk bidang pengajaran. ${ }^{19}$ Nilai yang besar ini tidak sebanding dengan subsidi yang diberikan kepada katholik dan kristen. Sekolah Muhammadiyah yang disubsidi pemerintah hanya 112 sekolah dari 416 sekolah yang dimilikinya, sedangkan katholik dan protestan semua sekolahnya disubsidi dengan masing-masing berjumlah 696 sekolah dan 1.893 sekolah. Alfan Alfian menyebutkan, Muhammadiyah hanya mendapat 1,5\% subsidi pemerintah Hindia Belanda, yaitu sebesar f 579,354.86 (1926), sedangkan total subsidi yang diberikan pemerintah kepada swasta sebesar f7,266,000. Subsidi ini ternyata bagi Muhammadiyah cukup memadai sekitar $15 \%$ dari total pemasukan dana persyarikatan.

Pemerintah kolonial memiliki beberapa pertimbangan penting untuk mempertahankan dukungannya pada Muhammadiyah. Pertama, "Muhammadiyah telah menjadi wadah aspirasi sosial bagi kaum pribumi muslim sehingga menghalanginya sama artinya memancing radikalisasi dan perlawanan kolektif pribumi muslim yang sangat kuat. Kedua, Sikap Muhammadiyah yang sangat kooperatif sangat dibutuhkan oleh pemerintah kolonial untuk menghadang radikalisasi pribumi oleh organisasi politik radikal seperti SI maupun ISDV (Partai Komunis). Ketiga, Kolonial cukup memiliki kepercayaan diri bahwa Muhammadiyah tetap tidak mampu mengubah status quo dikarenakan kapasitasnya yang masih sangat terbatas.

19 Lihat dalam Ahmad Adaby Darban, Sejarah Kauman: Menguak Identitas Kampung Muhammadiyah (Yogyakarta: UGM Press, 2000). Juga dalam Amelia Fauzia, Faith and State: A history Islamic Philanthropy in Indonesia (Leiden: Brill, 2013). 
Gambar; Hubungan Muhammadiyah, Negara Kolonial dan Gerakan Gereja

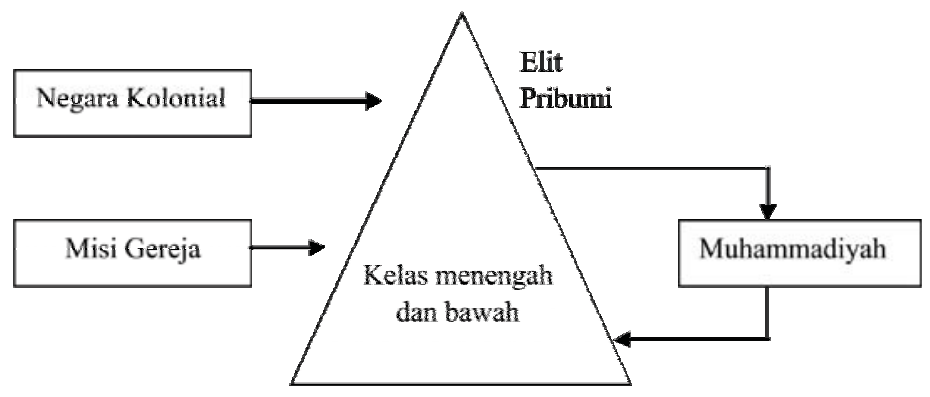

Kompetisi yang dilakukan Muhammadiyah dan negara kolonial berlangsung dalam dua ranah yang masing-masing dengan pendekatan strategi berbeda. Pertama, ranah Muhamammadiyah vis a vis negara. Kompetisi ini diwujudkan dengan adanya perbedaan aspirasi tujuan dan gagasan yang merasionalisasi lahirnya layanan kesejahteraan. Muhamamdiyah melakukan kompetisinya secara tertutup artinya tidak secara frontal melawan negara melainkan membangun hidden agenda yang merepresentasikan sikap perlawanannya sekaligus merangkul negara di permukaan. Hal ini diperkuat dengan adanya keterlibatan para pemimpin Muhammadiyah dalam aktivitas politik Syarekat Islam yang sangat frontal melawan kolonialisme. Kedua, ranah Muhammadiyah vis a vis quasy negara "Gereja".

Muhammadiyah menunjukkan sikap bertentangan dengan menghadang gerakan misi gereja dengan model yang fair, yaitu bersaing untuk menyediakan layanan untuk komunitas pribumi sekaligus bersaing untuk mendapatkan dukungan negara. Pilihan strategi ini terbukti berhasil mereproduksi banyak amal usaha Muhammadiyah tanpa menimbulkan konfrontasi antara Muhamamdiyah dan misi gereja secara fisik atau memicu konflik horizontal di masyarakat. Sebaliknya KH, Dahlan justru dikenal dekat dengan kalangan gereja dan berani untuk melakukan diskursus dengan para pendeta dan pastur. Di masa kepemimpinannya hampir tidak ada konflik terbuka yang terjadi antara kedua belah pihak.

\section{Pragmatisme di bawah Rezim Militer Jepang}

Sikap taktis dan pragmatis Muhammadiyah dalam memanfaatkan celah kekuasaan terus dipertahankan pasca jatuhnya kolonial Belanda pada bala tentara Jepang. Jepang memandang Muhammadiyah sebagai mitra strategis 
untuk mendukung legitimasi propaganda politiknya. Muhammadiyah diberi keleluasaan dengan prasyarat ia tunduk pada tujuan pendirian Asia Raya di bawah pimpinan Jepang dan melaporkan seluruh kegiatan dan administratif organisasinya. Mitsuo Nakamura menjelaskan, bahwa Jepang memanfaatkan Islam sebagai kekuatan antibarat dengan menempatkannya sebagai salah satu pilar propaganda. Para elit Muhammadiyah dimanfaatkan untuk memobilisasi kekuatan rakyat. KH. Mas Manshur, Ketua PP Muhammadiyah saat itu, ditunjuk untuk menjadi tiga serangkai pemimpin PETA (Pembela Tanah Air). Elit Muhammadiyah di berbagai daerah serta para guru sekolah Muhammadiyah juga banyak dijadikan pemimpin untuk gerakan para militer Jepang. Jepang juga memberikan kesempatan para tokoh muslim untuk membentuk Majelis Syuro Muslimin Indonesia (Masyumi) sebagai wadah aspirasi politik umat Islam.

Jepang tidak memprioritaskan pembangunan kesejahteraan sosial. Kebijakannya hanya berfokus pada mobilisasi dukungan untuk menghadapi Perang Pasifik. Pendidikan lebih diarahkan untuk menanamkan doktrin Asia Timur Raya. Dalam kondisi ini, peran penyediaan pendidikan dan kesehatan tetap dilakukan Muhammadiyah. Organisasi ini menolak doktrin Jepang, khususnya yang dianggap bertentangan dengan ajaran Islam, yaitu menolak seikirei atau hormat ke arah timur pada teno heika (kaisar Jepang). Muhammadiyah mengimbanginya dengan membentuk kesatuan tabligh khusus yang diterjunkan di Jawa dan Madura. Hal ini dilakukan dengan propaganda nasiolisme religius yang dibalut dakwah untuk melawan doktrin Jepang yang dianggap menjauhkan rakyat dari Islam. Beberapa sekolah dan kantor Muhammadiyah dijadikan pusat pengorganisasian yang aman karena secara formal Muhammadiyah mendapat jaminan pemerintah. ${ }^{20}$

Pada periode awal kemerdekaan keterlibatan Muhammadiyah dalam pelayanan sosial tidak terlihat dengan jelas. Muhammadiyah dan negara sama-sama berada dalam situasi yang sulit menghadapi revolusi kemerdekaan. Pada periode ini, Muhamamdiyah setidaknya memainkan beberapa peran. Pertama, peran politiknya dengan ikut serta mendirikan Partai Masyumi pada 1945 yang merupakan partai gabungan dari seluruh organisasi muslim saat itu. Peran politik itu mampu mendukung upaya-upaya diplomatik dan pembangunan negara melalui tokohtokoh Muhammadiyah di pemerintahan. Kedua, peran perjuangan fisik melawan agresi militer belanda melalui para anggotanya yang meleburkan diri ke Hizbullah.

20 Syarifudin Jurdi, Muhammadiyah dalam Dinamika Politik Indonesia 1966-2006 (Yogyakarta: Pustaka Pelajar, 2010), h. 118. 
Ketiga, Muhammadiyah berusaha mempertahankan seluruh fasilitas pendidikan dan kesehatannya dan dukungan finansial untuk perjuangan fisik. Amelia Fauzia menyebutkan, pada fase perjuangan kemerdekaan filantropisme dari dana Ziswaf lebih banyak terkuras untuk mendanai jihad dalam rangka perang kemerdekaan. Jihad ini dilakukan kalangan muslim untuk mengorganisir diri dan mempertahankan kemerdekaan dalam wadah Hizbullah yang diinisiasi para tokoh Masyumi di berbagai daerah.

Pasca perjuangan revolusi kemerdekaan Muhammadiyah masih dihadapkan pada fase yang sulit dalam dinamika politik. Muhammadiyah yang terlibat dalam Masyumi lebih fokus memperjuangkan gerakan politiknya dari level elit hingga akar rumput yang ditunjukkan dengan mobilisasi politik anggotanya untuk memenangkan Masyumi pada pemilu 1955. Pasca Pemilu 1955, pergulatan elit tentang dasar negara di konstituante menjadi fokus perhatian yang juga menyita energi akar rumput untuk memobilisasi dukungan ekstra parlementer.

Pasca dibubarkannya konstitunate pada 1959, Soekarno menerapkan kebijakan demokrasi terpimpin yang berpayung pada gagasan Nasionalisme, Sosialisme dan Agama (Nasakom). Muhammadiyah sebagai bagian dari Masyumi mengambil jalan bersebrangan dengan gagasan tersebut yang menimbulkan ketegangan dengan rezim. Puncaknya, Muhammadiyah mengalami ketegangan dengan negara pasca dibubarkannya Masyumi (1960). Masyumi (dan juga PSI) dibubarkan akibat para tokohnya terbukti terlibat dalam gerakan Pemerintahan Revolusioner Republik Indonesia (PRRI) / Perjuangan Rakyat Semesta (Permesta) yang menuntut penerapan otonomi daerah. Di sisi lain ketegangan politik ideologis antara Muhammadiyah dengan PKI (pengusung utama Nasakom) menjadikan Muhammadiyah sebagai sasaran empuk bagi provokasi komunis yang menyebut Muhammadiyah sebagai kontra revolusioner dan sebagai sarang eks-eks partai "terlarang" Masyumi. PKI menuntut Soekarno untuk membubarkan Muhammadiyah.

Di tengah konflik politik yang terus terjadi, Muhammadiyah memainkan fungsi politik taktisnya dengan merangkul salah satu elemen kekuatan negara. Muhamamdiyah membangun kemitraan strategis dengan Angkatan Darat (AD) yang antikomunis. Para pemimpin Muhammadiyah memanfaatkan kedekatannya dengan para pemimpin AD yang eks Hizbullah dan eks Peta. Simbiosis ini terbukti dengan kesediaan Jendral AH. Nasution (Menteri Pertahanan) dan Jendral Polisi Judo Sutjipto melatih Pemuda Muhammadiyah untuk membentuk 
Komando Keamanan Muhammadiyah (KOKAM) dalam rangka menghadapi komunisme (1965). Kokam tampil secara heroik di bawah propaganda AD untuk terlibat dalam penangkapan para aktivis PKI yang nantinya menjadi pembantaian massal. Seluruh basis massa Muhammadiyah dan AUM-nya dijadikan alat konsolidasi bagi kekuatan antikomunis. Muhammadiyah selama fase Orde Lama terlalu banyak mengambil peran politik dibandingkan peran sosialnya. Aktivisme sosial Muhammadiyah sekedar mempertahankan apa yang sudah ada tanpa sebuah upaya sistematis.

\section{Membangun Bersama Negara (Fase Orde Baru)}

Jatuhnya Soekarno menandai fase Orde Baru yang sangat pro pada pembangunan. Pembangunan menjadi semboyan utama Orde Baru untuk memperbaiki kondisi sosial, ekonomi dan stabilitas politik. Soeharto menjanjikan upaya perbaikan ekonomi yang terpuruk akibat hiperinflasi di akhir masa Orde Lama. Orde Baru berusaha membangun kembali fondasi ekonomi dengan mengandalkan kebijakan industrialisasi yang disebut dengan Rencana Pembangunan Lima Tahun (Repelita) yang dijalankan sejak 1969. Industrialisasi yang sangat permisif terhadap modal asing dijadikan fondasi awal bagi bangunan ekonomi Orde Baru.

Pemerintah orde baru berusaha serius melakukan upaya pembangunan sosial yang ditekankan pada tiga aspek; (1) menekan angka kemiskinan, (2) menyediakan fasilitas pelayanan dasar pada sektor pendidikan dan kesehatan, (3) memobilisasi potensi masyarakat untuk terlibat dalam upaya-upaya peningkatan kualitas kesejahteraan. Keefektifan kebijakan sosialnya dibuktikan dengan penurunan angka kemiskinan secara bertahap. Pada tahun 1970 kemiskinan di Indonesia mencapai angka $60 \%$ atau sekitar 70 juta orang berhasil turun secara signifikan pada periode 1980 hanya tersisa $33.3 \%$ atau 42.3 juta orang dan tinggal $15.1 \%$ atau 27,2 juta orang pada 1990 dan tersisa hanya $11,3 \%$ atau 22,5 juta jiwa penduduk miskin pada era 1996 (fase sebelum anomali akibat krisis finansial 1996-1998).

Keefektifan negara pada masa Orde Baru juga ditunjukan dengan kemampuannya dalam merespon tuntutan publik. Pada periode ini publik cenderung menuntut perlunya dua hal, pertama, pemenuhan kebutuhan dasar berupa pemenuhan kebutuhan sandang, pangan, papan dan akses layanan pendidikan dan kesehatan. Julie Chernov Hwang menyebutkan, Orde Baru 
memainkan peran utama dalam penyediaan pendidikan dan kesejahteraan. Rezim mengamankan legitimasinya dengan kemampuannya yang berhasil memastikan stabilitas dan kemakmuran berkelanjutan. Penyediaan pendidikan dasar universal, swasembada beras, dan pengurangan drastis jumlah kemiskinan adalah puncak pencapaian Soeharto.

Di tingkat lokal, rezim itu memberlakukan serangkaian kebijakan yang disebut instruksi presiden (Inpres), yang menyediakan dana untuk memperbaiki infrastruktur dan bantuan pembangunan bagi pemerintah-pemerintah daerah.

Pada pertengahan 1980-an, negara membangun pusat-pusat kesehatan masyarakat di setiap kecamatan dan mengaspal jalan yang menghubungkan daerah perdesaan dengan pusat-pusat perkotaan. Pemerintah berusaha memastikan bahwa semua anak, bahkan mereka yang tinggal di daerah-daerah terpencil, punya akses pada pendidikan dasar yang murah, dan membangun ribuan sekolah dasar baru untuk memenuhi permintaan akan pendidikan. Mulai akhir 1970-an, Orde Baru mempercepat pembangunan rumah sakit dan klinik, membangun lebih dari 26.000 pusat kesehatan masyarakat dan pusat kesehatan masyarakat pembantu. ${ }^{21}$

Di balik kapasitas negara dalam memberikan kesejahteraan pada masyarakat, negara cenderung menampilkan wajah otoritarian dan represif terhadap aktoraktor yang bersebrangan. Pemerintah Orde Baru juga mengembangkan paradigma negara integralistik yang menggunakan model korporatokratif. ${ }^{22}$ Negara menjadi puncak hirarkis kekuasaan dan tidak memberikan ruang di luar strukturnya untuk berkembang.

Seluruh aspirasi masyarakat disalurkan melalui jalur-jalur resmi yang disediakan negara. Represi politik juga dilakukan pada seluruh pandangan politik oposisi yang dianggap bertentangan dengan ajaran resmi negara atau berpotensi melahirkan oposisi. Remy Mardiner menjelaskan, salah satu bentuk represif tersebut dengan melarang kemunculan beberapa tokoh politik Islam dalam pentas politik. Dalam kondisi seperti ini Muhammadiyah berhasil melepaskan diri dari ruang politik sehingga cukup diterima sebagai mitra utama negara.

21 Julie Chernov Hwang, Umat Bergerak: Mobilisasi Damai Kaum Islamis di Indonesia, Malaysia dan Turkti (Jakarta: Freedom Institute, 2001), h. 99-100.

22 Negara korporatokrasi yaitu negara yang berusaha menempatkan seluruh dimensi dan kehidupan sosial masyarakat dibawah payung saluran resmi negara guna menjadi mobilisasi legitimasi politik dan sistem rekruitmen elit politik (Nasikun, 2004). 
Awalnya Muhammadiyah menjadi bagian dari Parmusi, tetapi Kongres di Ujung Pandang Muhammadiyah mendeklarasikan diri netral politik dan menjaga hubungan yang sama dengan semua kekuatan politik pada 1971. Robert W. Hefner mengatakan, netralitas ini cenderung didukung Orde Baru yang sangat berharap akan adanya peran Islam sebagai kekuatan moral spiritual yang berdampingan dengan pembangunan.

Di bawah kepemimpinan AR Fachrudin (1968-1990), ${ }^{23}$ Muhammadiyah memilih jalur akomodatif, dialogis. Bahkan pimpinan Muhammadiyah yang akrab disapa pak AR tersebut dikenal memiliki kedekatan spesial dengan Soeharto. Sosoknya yang lugu dan santun serta njawani menjadikan Soeharto merasa 'pekewuh' dengan Muhammadiyah. Pilihan politik ini membuka hubungan simbiosis mutualisme antara Muhammadiyah dan pemerintah, terutama dengan dukungan pemerintah terhadap seluruh aktivisme sosial dan keagamaan Muhammadiyah. ${ }^{24}$

Pemerintah memandang positif kemampuan Muhammadiyah untuk mendorong lahirnya keswadayaan dan kolektifisme di masyarakat, khususnya para anggotanya. Negara mendukung sepenuhnya dengan memberikan bantuanbantuan melalui pemerintah baik pusat maupun lokal. Situasi ini terjadi dikarenakan dua faktor. Pertama, anggota-anggota Muhammadiyah sudah banyak yang berada dalam birokrasi pemerintah di berbagai level. Kedua, Muhammadiyah tetap konsisten untuk tidak terlibat dalam pergulatan politik secara resmi sehingga mampu menjaga jarak yang cukup aman dengan negara. Hwang menyebutkan dengan mengutip pendapat Abdul Mu'ti yang menjelaskan bahwa Muhammadiyah adalah organisasi nonpolitis yang berfokus pada berbagai layanan sosial.

Hwang berpendapat, pemerintah mendapatkan legitimasi dari kesanggupannya memastikan keberhasilan dalam menyediakan pendidikan dan memerangi kemiskinan di tingkat makro. NU dan Muhammadiyah membantu di tingkat mikro dan lokal. Muhammadiyah memanfaatkan kedekatannya dengan

23 AR. Fachrudin menolak dijadikan ketua pada 1990, sehingga digantikan KH. Azhar Bashir dan Beliau menduduki posisi dewan penasehat sampai wafatnya 1995, Kedekatanya dengan Presiden Soeharto ditunjukan dengan pengangkatan dirinya sebagai Dewan Pertimbangan Agung (DPA) periode 1988-1993. Tentang AR, Fachrudin selengkapnya Lihat Suara Muhammadiyah No. 07/80/ 1995, h. 18-22.

$24 \quad$ Sejak Muktamar 1971 di Ujung Pandang dideklarasikan keputusan Muhammadiyah untuk menjaga jarak yang sama dengan semua partai politik sebagai sikap netralitas atau high politic Muhammadiyah (lihat Suara Muhamamdiyah, No. 13 tahun 85/ Juli 2000, di suplemen jendela persyarikatan, h. 6. 
negara untuk membangun banyak fasilitas pendidikan mulai dari taman kanakkanak hingga universitas, klinik dan rumah sakit, panti asuhan dan lain-lain yang hampir kesemuanya selalu didukung oleh aktor dalam pemerintahan, baik di level pusat hingga level daerah, cabang dan ranting. Sebagaimana dituturkan Nurul Chusna Sekretaris MPKU PWM DIY:

"Saat pembangunan rumah sakit Muhammadiyah selalu mengundang para pejabat pemerintah di berbagai level, termasuk para anggota muhammadiyah yang berada di pemerintah pusat utamanya menteri untuk membantu menggalang dana pembangunan." ${ }^{25}$

Legitimasi dan dukungan dari para elit pemerintahan menjadikan Muhammadiyah terus berkembang pesat. Di sisi lain, gerakan akar rumput yang digerakan ranting, cabang dan daerah tidak pernah henti setiap tahun menginisiasi keinginan untuk membangun amal usahanya. Sebagaimana dituturkan Muhammad Hatta, sekretaris Muhammadiyah PCM Kota Gede

"Kami sejak dulu selalu merencakan setiap tahun perlu membangun apa? setidaknya merenovasi atau penambahan fasilitas untuk amal usaha, itu hampir semuanya didapat dari donasi para jamaah Muhammadiyah termasuk mereka yang sejak muda aktifis Muhammadiyah dan kini sudah sukses dan tersebar dimana-mana." 26

Dilihat dari motifnya, Muhammadiyah cenderung mempertahankan patronasenya dengan negara dan menjadi penguat legitimasi negara di masyarakat sebagaimana dikatakan Egbert Harmsen (2008) ketika negara memberikan peluang bagi civil society. Negara cenderung mendapat keuntungan dengan menjadi puncak dari patronase tersebut, sedangkan civil society yang lahir cenderung menjadi salah satu segmen terbatas dalam pembentukan patronase di masyarakat bertingkat dengan menempatkan dirinya sebagai representasi masyarakat untuk menjadi segmentasi patronase yang berpuncak kepada negara. Posisi ini mendatangkan keuntungan bagi Muhammadiyah dengan privilege yang diberikan oleh negara.

\section{Era Reformasi: Bertahan di Celah Kekuasaan}

Hubungan mesra Muhammadiyah dengan negara sempat renggang pada pertengahan dekade 1990-an. Muhammadiyah yang dipimpin M. Amien Rais

25 Wawancara dengan dr Nurul Chusna, Sekretaris MPKU PWM DIY, pada 17 Januari 2014.

26 Wawancara dengan Drs. Muhammad Hatta, Sekretaris PCM Kota Gede, pada 16 Januari 2014. 
(Ketua PP Muhammadiyah 1994-1998), memulai dinamika kritisnya terhadap Orde Baru dengan menyatakan perlunya suksesi kepemimpinan. ${ }^{27}$ Arus utama gerakan Reformasi berhasil menuntut mundur Presiden Soeharto dari tampuk kepemimpinan setelah 32 tahun berkuasa.

Muhammadiyah mempertahankan posisi netral dengan menempatkan diri mengambil jarak dengan politik. Muhammadiyah mempertahankan sifat politik alokatif atau memberikan porsi kedekatan yang sama dengan semua kekuatan partai politik. Pilihan ini cenderung menjadikan Muhammadiyah sebagai aset sosial bagi seluruh kekuatan politik.

Setelah Soeharto jatuh, lalu pemerintahan dipegang Habibie, saat itulah muncul Undang-Undang Pengelolaan Zakat yang muncul sebagai respons terhadap dua perkara; Pertama, kebutuhan mendesak dengan mendorong keterlibatan masyarakat dalam mengatasi krisis ekonomi. Kedua, adanya tuntutan komunitas muslim sebagai kekuatan politik yang besar, dengan mengingatkan Habibie sendiri sebagai ketua ICMI. ${ }^{28}$

Menurut Widyawati, kelahiran UU Zakat sebenarnya muncul sejak pertengahan 1990-an, dimana Harian Umum Republika (sayap media ICMI) menelurkan lahirnya Dompet Dhuafa sebagai lembaga amil zakat. Gerakan ini juga direspons positif oleh berbagai pihak sebgai model alternatif dalam tren filantropi Islam di Indonesia yang dianggap lebih profesional dan transparan. Kemudian, Dompet Dhuafa menjadi motor gerakan zakat melalui Forum Zakat (FOZ) yang berhasil menghimpun banyak elemen pengelola zakat baik dari pemerintah, NGO maupun lembaga zakat karyawan yang berafiliasi dengan perusahaan. FOZ akhirnya berhasil mengajukan draft RUU Pengelolaan Zakat kepada BJ. Habibie dan diajukan sebagai inisiatif pemerintah ke DPR yang dalam waktu singkat disahkan menjadi undang-undang.

Sayangnya, Muhammadiyah terlambat merespons adanya gerakan zakat ini dan masih terus mempertahankan praktik pengelolaan zakatnya yang konvensional

27 Sebagian pengamat melihat bahwa fase kritis ini dikarenakan adanya sosok Amien Rais yang muncul sebagai ketua umum pasca muktamar Aceh, 1995 yang tepat beriringan dengan meninggalnya dua pimpinan yang akomodatif yaitu KH. AR. Fachruddin dan KH. Azhar Bashir, dan Muhammadiyah tidak sepenuhnya kritis terhadap pemerintah tokoh muda Muhammadiyah seperti Dien Syamsudin (mantan ketua pemuda Muhammadiyah) saat itu justru mendekat ke orde baru dan berusaha mempertahankan relasi strukturalnya dengan bergabung dengan Golkar dan ICMI. Lihat Robert. W. Hefner, Civil Islam: Muslim and Democratization in Indonesia (Pricenton University Press: UK, 2000), h. 149-150.

28 Widyawati, Filantropi Islam dan Kebijakan Negara Pasca Orde Baru: Studi tentang Undang-Undang Zakat dan Undang-Undang Wakaf (Jakarta: Sekolah Pasca Sarjana UIN Syarif Hidayatullah, 2001). 
dengan basis dari anggotanya. Namun, pasca kepemimpinan singkat BJ, Habibie, Amien Rais mampu membangun koalisi poros tengah untuk mengangkat Abdurahman Wahid -Ketua Umum PB NU- sebagai presiden dengan tetap membawa beberapa orang Muhammadiyah di kabinet. Begitu juga di masa kepemimpinan Megawati Soekarno Putri (2001-2004) dan Susilo Bambang Yudhoyono (2004-2013), para elit Muhammadiyah tidak absen mewarnai kekuasaan baik di eksekutif maupun legislatif melalui berbagai partai politik.

Di era reformasi sifat korporatis negara untuk menguasai aktor-aktor sosial semakin melemah. Di sisi lain telah muncul pergeseran tuntutan publik yang ingin mendapatkan layanan kesejahteraan yang lebih berkualitas sementara layanan yang diberikan negara seringkali gagal merespons tuntutan ini akibat keterbatasan fiskal dan birokrasinya yang tidak responsif sehingga menjadikan negara terlihat semakin kurang efektif. ${ }^{29}$ Kondisi demikian tidak mengubah sikap Muhammadiyah yang secara terbuka tetap memberikan dukungan kepada negara.

Negara meresponnya secara positif dengan memberikan porsi pada kaderkader Muhammadiyah untuk terlibat di pemerintahan. Relasi simbiosis mutualistik ini menjadikan Muhammadiyah tetap mempertahankan kolaborasinya dengan negara.

Pasca Reformasi, Muhammadiyah dituntut untuk mempertahankan model pelayanan berbasis amal usahanya. Model layanan berbasis AUM menjadikan peran yang dimainkannya sama dengan layanan yang direproduksi pemerintah. Posisi ini menjadikan Muhammadiyah tidak bergeser sebatas melengkapi peran negara. Pilihan tersebut menjadikan nilai kemanfaatan Muhammadiyah terlokalisir di wilayah basis-basisnya. Sebagaimana dikatakan Said Tuhuleley;

"bertahun-tahun Muhammadiyah sibuk membantu negara membangun banyak sekolah, rumah sakit, panti asuhan dan lain-lain, tapi semuanya harus dihidupi sendiri sehingga Muhammadiyah disibukan dengan urusan ini, ini menjadikan kita agak terlambat merespon kebutuhan untuk mengatasi masalahmasalah di lapangan." ${ }^{30}$

Kesibukan Muhammadiyah dalam mempertahankan layanan berbasis AUM menjadikannya tejebak pada rutinitas. Sebagaimana kritik yang dilontarlan sa;ah

29 Tentang perubahan tuntutan publik dan responsifitas administratif dan birokrasi negara bisa dilihat dalam Rhee Jeeyang Baum, Responsive Democracy: Increasing State Accountability in East Asia (USA: The Michigan University Press, 2011), h. 4.

30 Wawancara dengan Said Tuhuleley, Ketua MPM PP Muhammadiyah pada 16/1/2014. 
satu angkatan muda Muhammadiyah, Zuly Qodir. Dia mengungkapkan, seringkali Muhammadiyah terkesan sibuk dengan urusan membangun sekolah dan amal usaha yang lain, tetapi tidak tahu setelahnya untuk apa? Idiomnya yang penting membangun, lalu merawatnya belakangan saja.

Muhammadiyah terkesan lambat dalam merumuskan formulasi aktivisme sosial yang lebih taktis. Keterlambatan ini juga disebabkan karena rentang organisasi yang panjang dan membuatnya perlu energi ekstra untuk keluar dari zona nyaman, khususnya dalam pemanfaatan potensi filantropi di internal organisasi. Dalam hal ini Nurul Chusna mengatakan, Muhammadiyah ini institusi besar, beragam latarbelakang anggotanya. Jumlah amal usahanya juga sangat banyak dan kemampuannya tidak seragam sehingga tidak mudah mengubah pola kerja organisasi ini secara keseluruhan. Perlu edukasi dan penyadaran agar tumbuh inisiatif dari cabang dan ranting. ${ }^{31}$

Meskipun Gerakan Muhammadiyah secara umum terlambat merespon tren gerakan filantropisme baru tetapi Muhammadiyah di akar rumput telah melahirkan inisiatif mandiri untuk bergerak memberikan layanan sosial yang tidak bisa disepelekan. Pada level cabang dan ranting, mereka aktif melakukan aktivisme sosialnya. Muhammadiyah masih memainkan aktivisme sosial secara sporadis dengan inisiatif masing-masing jejaringnya.

Kehadiran layanan berbasis komunitas di akar rumput memberikan kekuatan bagi Muhammadiyah dalam memperkuat pengaruh di basis-basisnya, sekaligus memberikan kontribusi nyata di tengah sulitnya situasi ekonomi mengingat saat itu pemerintah sering mengambil kebijakan menaikkan harga BBM. Kebijakan penaikan BBM memang diantisipasi dengan penyelenggaraan jaminan sosial dan kompensasi yang meliputi: Raskin, beasiswa tidak mampu, biaya operasional pendidikan, dan yang lainnya. Berbagai program itu belum cukup efektif untuk mengentaskan masyarakat dari masalah kemiskinan. Untuk itu, dalam merespons situasi ini, Muhammadiyah berusaha menelurkan terobosan baru terutama dengan munculnya gagasan Neo-PKO yang menjelma menjadi Muhammadiyah Disaster Manegement Center (MDMC), Lembaga Buruh, Tani dan Nelayan (LBTN) yang berubah menjadi Majelis Pemberdayaan Masyarakat (MPM), Lembaga Zakat Amil dan Shadaqah Muhammadiyah (Lazismuh) dan Baitul Tamwil Muhammadiyah (BTM).

31 Wawancara dengan dr. Nurul Chusna, Sekretaris MPKU PWM DIY pada 17 Januari 2014. 
Berbagai lembaga ini adalah bentuk kesadaran Muhammadiyah untuk merespons masalah sosial. MDMC banyak terlibat secara intensif dalam proses penanggulangan bencana. Sedangkan MPM berusaha selalu di garis depan dalam memberdayakan petani dan pekerja sektor informal di berbagai daerah. Gerakan MPM juga direproduksi di berbagai daerah (kota/kabupaten) dan cabang (kecamatan) di berbagai pelosok nusantara.

Di sisi lain, Lazismuh hadir dengan berusaha untuk memberikan wajah baru pengelolaan zakat yang profesional dengan membangun sinergi jaringan, baik di level wilayah, daerah, cabang hingga amal usaha muhamamdiyah. Adapun BTM berusaha mengakumulasikan kekuatan ekonomi akar rumput jamaah Muhammadiyah untuk mendorong pertumbuhan ekonomi akar rumput di sektor micro finance. Gerakan ini menjadi tren baru yang memiliki pengaruh besar sebagai wujud komitmen baru Muhammadiyah dalam mengatasi berbagai masalah kemiskinan.

Peran Muhammadiyah dalam mendorong peningkatan kesejahteraan sosial tidak bisa dilepaskan dari modal yang dimilikinya. Muhammadiyah memiliki tiga modal besar dalam upaya tersebut. Pertama, aset amal usaha yang ribuan dan berbagai macam jenis yang tersebar di seluruh Indonesia. Kedua, "keberadaan anggota dan jamaahnya serta jejaring organisasi yang tersebar luas di seluruh wilayah Indonesia. Ketiga, keberadaan para elit muhammadiyah yang memiliki posisi strategis baik di dalam maupun diluar pemerintahan. Ketiga modal itu menjadikan Muhammadiyah secara institusional mampu memainkan dua peran sekaligus, yaitu melakukan redistribusi sumber daya melalui aktivisme sosial dan mendorong negara untuk melakukan perbaikan kualitas kebijakannya dalam mengatasi masalah sosial. Dalam hal ini, Said Tuhuleley menyampaikan:

"MPM konsen tidak hanya pemberdayaan tapi juga advokasi kebijakan, kami mendiskusikannya dan melakukan pressure terhadap pemerintah, Pak Dien (Dien Syamsudin, Ketua Umum PP Muhammadiyah) juga mengambil peran strategis salah satunya dengan melakukan judicial review undang-undang yang dianggap melanggar konstitusi, kemaren kita berhasil men-JR UU Migas dan terus bergerak ke sektor-sektor lain khususnya terkait kebijakan pangan, kami juga buat pillot project sekaligus labolatorium pemberdayaan petani di Sawangan, Magelang, itu untuk memberi contoh pemerintah bagaimana seharusnya menangani petani, kami juga terlibat pemberdayaan buruh gendong, abang becak, hingga komunitas suku pedalaman di Sorong" ${ }^{32}$

32 Wawancara dengan Drs. Said Tuhuleley, Ketua MPM PP Muhammadiyah, pada 16 januari 2014. 
Kemampuan memainkan dua peran ini khas dimiliki Muhamamdiyah yang memiliki basis legitimasi dan pengakuan yang cukup besar dihadapan publik dan negara. Walaupun demikian, Muhammadiyah belum memiliki desain sistematis dalam merancang gerakan filantropinya. Muhammadiyah masih berusaha memadukan konsolidasi gerakan amal usahanya yang berjumlah ribuan dengan sistem filantropi yang berakar pada komunitas akar rumput di cabang dan ranting. Di sisi lain, Muhamamdiyah perlu juga mengantisipasi gelagat kebijakan negara dnegan melakukan advokasi terhadap berbagai kebijakan negara.

\section{Penutup}

Muhammadiyah merupakan satu contoh dari eksistensi komunitas masyarakat dalam rangka menciptakan kesejahteraan sosial. Dalam sistem welfare pluralisme, kehadiranya sangat membantu dalam rangka memperkuat modal sosial di masyarakat. Muhammadiyah yang lahir dari dorongan nilai-nilai ajaran Islam mampu mereproduksi sebuah layanan kesejahteraan, baik berupa fasilitas dan pelayanan baik pendidikan, kesehatan, ekonomi dan sosial maupun dalam bentuk santunan langsung dan pemberdayaan. Motif awal kelahiran Muhammadiyah muncul sebagai respons atas kondisi sosial di zamannya dan kemudian berkembang menjadi tradisi dalam lembaga yang terus direproduksi dan dipertahankan hingga kini sebagai sebuah identitas gerakan.

Muhammadiyah tumbuh dari asossiasi sosial keagamaan menjadi organisasi yang memiliki jejaring birokrasi yang panjang dan memiliki kekuatan sosial dan ekonomi yang menggurita. Kolektivisme anggotanya yang dibalut dengan identitas religius melahirkan semangat pembaharuan yang berurat pada upaya membangun kekuatan praktis organisasi dalam menyediakan layanan pendidikan, kesehatan dan sosial. Kemampuan Muhammadiyah memberikan layanan menjadikannya meraih legitimasi sebagai patron melalui proses pembentukan "authority ranking" pada komunitas pribumi.

Muhammadiyah berusaha menarik sumber daya kolektif publik khususnya para anggotanya, sekaligus berusaha mendekati negara untuk ikut serta mengalokasikan anggarannya untuk memberikan subsidi dan bantuan hibah yang dilakukan dengan mengandalkan koneksivitas para elitnya yang juga berada di ruang-ruang birokrasi dan politik. Selain itu Muhammadiyah melalui sayapsayap geraknya berusaha pula untuk mengakses dana-dana dari donor-donor 
internasional untuk mempertahankan aktivisme sosial utamanya di kawasan bencana.

\section{Motif Layanan Kesejahteraan Muhammadiyah}

\begin{tabular}{|c|c|l|}
\hline \multicolumn{1}{|c|}{ Institusi } & Motif & \multicolumn{1}{c|}{ Proses } \\
\hline Muhamamdiyah & $\begin{array}{l}\text { Authority } \\
\text { Ranking }\end{array}$ & $\begin{array}{l}\text { Ziswaf diakumulasikan dari basis solidaritas } \\
\text { anggotanya untuk membangun fasilitas pelayanan, } \\
\text { menunjang aktivismenya dan sebagian distribusi } \\
\text { langsung ke fakir miskin }\end{array}$ \\
\hline
\end{tabular}

Relasi pelayanan kesejahteraan yang disediakan Muhammadiyah dengan negara cenderung adaptif dengan celah struktur politik yang dihadapinya. Relasi pelayanan tersebut sangat bergantung pada dua faktor, yaitu: Kapasitas dan tujuan negara yang dihadapinya dan pilihan strategi lembaga dalam menjalankan aktivisme sosial. Di level elit Muhammadiyah berusaha merespons insentif yang diberikan negara kepadanya, sedangkan di level akar rumput Muhammadiyah cenderung independen dari pengaruh negara dan lebih mendasarkan pada inisiatif kolektif kader-kadernya.

Relasi Muhammadiyah dengan negara bisa dikategorikan dalam dua fase, yaitu fase kompetisi dan komplementer. Fase kompetisi diimplementasikan selama era kolonialisme, di mana Muhammadiyah sebagai pengusung aspirasi pribumi menempatkan tujuan yang berbeda dengan negara kolonial. Negara kolonial membawa misi untuk mempertahankan kolonialisasi, stratifikasi sosial dan juga upaya pembaratan Hindia, sedangkan Muhammadiyah menginginkan kesetaraan kaum pribumi dan penciptaan masyarakat Hindia yang religius. Selain itu, pada fase ini Muhammadiyah menampilkan dua wajah, yaitu melakukan usaha kompetisi tertutup dengan pemerintah dalam melakukan layanan kesejahteraannya dan melakukan kompetisi terbuka dengan quasy pemerintah "pihak gereja" tanpa menimbulkan konfrontasi melainkan dengan model peniruan taktis.

Sedangkan"fase komplementer berlangsung pasca kemerdekaan, khususnya di era Orde Baru yang ditandai kesamaan tujuan Muhamamdiyah dan negara serta efektifitas layanan negara. Muhammadiyah membangun sinergistas terhadap agenda pembangunan yang diusung negara dengan berusaha menopang negara melalui reproduksi layanan pendidikan, sosial dan kesehatan. 
Aktivisme sosial Muhammadiyah dengan segala keterbatasannya telah menjadi pilar penyangga kesejahteraan, khususnya bagi kaum marginal yang belum tersentuh oleh negara. Kekuatan akar rumput Muhammadiyah baik kolektif maupun kesadaran individual kadernya menjadi salah satu pilar untuk merawat solidaritas, kepedulian dan kerelawanan di masyarakat.

Kehadiran Filantropisme ternyata bukan hanya menjadi potret kesadaran humanisme dan kepedulian, melainkan memiliki pertautan dalam konteks sosial politik yang berkembang antara masyarakat dan negara, sekaligus menciptakanya sebagai modal sosial dalam membangun relasi dan pengaruh dengan negara dan masyarakat sekaligus.

Kehadiran Muhammadiyah sebagai volunteer sector memberikan tiga pengaruh signifikan. Pertama, memperkuat sumber daya yang dimiliki negara di masa krisis maupun di masa perekonomian yang baik dalam rangka penyelenggaraan layanan sosial. Kedua, merawat solidaritas kolektif masyarakat dan menekan ketergantungan masyarakat pada layanan sosial negara. Ketiga, menjadi kekuatan penyeimbang dan penopang ketika negara dengan sengaja mengabaikan kewajibanya menyediakan layanan kesejahteraan pada masyarakat seperti di era kolonial.

Dengan demikian komitmen Muhammadiyah dalam mendorong kesejahteraan tidak kontraproduktif dengan tujuan lahirnya negara maupun welfare state. Peran ini jauh berbeda dengan konsepsi beberapa kelompok islamis, baik di dalam maupun di luar negeri yang memanfaatkan gerakan filantropi untuk menggerogoti legitimasi negara. Secara konsepsional gagasan pelayanan sektor ketiga a la Muhammadiyah yang bersifat inklusif (bukan untuk kelompoknya saja) bisa direproduksi dan diperkenalkan sebagai buffer system untuk menopang welfare state yang tengah mengalami keterbatasan di tengah perekonomian dunia yang sedang tidak terlalu kondusif.

\section{Bibliografi}

Alfian, Alfan, Politik Kaum Modernis: Perlawanan Muhammadiyah terhadap Kolonialisme Belanda, Jakarta: Al Wasat, 2012.

Al Makassary, Ridwan, "Pengarus Utamaan Filantropi Islam untuk Keadilan Sosial di Indonesia: Proyek yang Belum Selesai,” Jurnal Galang, Vol. 1, No. 3, April 2006.

Baum, Rhee Jeeyang, Responsive Democracy: Increasing State Accountability in East Asia, USA: The Michigan University Press, 2011. 
Beik, Irfan Syauqi dan Laily Dwi Arsyianti, Optimization of Zakat Instrument in Indonesia's Poverty Alleviation Program, yang diakses melalui http:// www.seadiproject.com/0_repository/-Session \%203C\%20-\%20Irfan\%20Syauqi\%20Beik(1).pdf pada 20 November 2013.

Boy Ztf, Pradana, M. Hilmi Faiq dan Zulfan Barron (ed.), Era Baru Gerakan Muhammadiyah, Malang: UMM Press, 2008

Darban, Ahmad Adaby, Sejarah Kauman: Menguak Identitas Kampung Muhammadiyah, Yogyakarta: UGM Press, 2000.

Dixon, John dan Robert P. Scheurrel (ed.), Social Welfare in Indigenous People, London: Routledge, 1995.

Fauzia, Amelia, Faith and State: A history Islamic Philanthropy in Indonesia, Leiden: Brill, 2013.

Gourevich, Peter A., et. al., The Political Science of Peter. J. Katzeinstein, American Political Science Association, 2008.

Harmsen, Egbert, Islam, Civil Society and Social Work: Muslim Voluntary Welfare Association in Jordan between Patronage and Empowerment, Leiden: Amsterdam University Press, 2008.

Hefner, Robert W., Civil Islam: Muslim and Democratization in Indonesia, UK: Pricenton University Press, 2000.

Helmke, Gretchen, dan Steven Levitsky, Informal Institution and Comparative Politics: A Research Agenda, Kellog Institute: Working Paper \#307, September 2003.

Heriej, Erieck, Ucu Martanto dan Ahmad Musyadad (ed.), Politik Transisi Pasca Soeharto, Yogyakarta: FISIPOL UGM, 2004.

Hunsaker, J. dan B. Hanzl, "Memahami Filantropi Keadilan Sosial," Jurnal Galang, Vol. 1, No. 1, Oktober 2003.

Hwang, Julie Chernov, Umat Bergerak: Mobilisasi Damai Kaum Islamis di Indonesia, Malaysia dan Turkti, Jakarta: Freedom Institute, 2011.

Ife, Jim, dan Frank Tesoriero, Community Development: Alternatif Pengembangan Masyarakat di Era Global, Yogyakarta: Pustaka Pelajar, 2008.

Jahar, Asep Saepudin, "Masa Depan Filantropi Islam di Indonesia: Kajian Lembaga-Lembaga Zakat dan Wakaf," Annual Conference in Islamic Studies (ACIS) ke 10, Banjarmasin, 1-4 November 2010.

Jurdi, Syarifudin, Muhammadiyah dalam Dinamika Politik Indonesia 1966-2006, Yogyakarta: Pustaka Pelajar, 2010. 
Jurdi, Syarifudin (ed.), Satu Abad Muhamamdiyah: Gagasan Pembaharuan Sosial Agama, Jakarta: Kompas, 2010.

Kozlowski, Gregory C. "Otoritas Agama, Reformasi dan Filantropi di Dunia Islam Kontemporer," dalam Ilchman, E Warren, et. al., Filantropi di Berbagai Tradisi Dunia, Jakarta: Center of the Study of Religion and Culture, 2006.

Komter, Aafke A., Social Solidarity and the Gift, Cambridge: Cambridge University Press, 2005.

Kurasawa, Aiko, Mobilisasi dan Kontrol: Studi tentang Perubahan Sosial di Pedesaan Jawa 1942-1945. Jakarta: Grasindo, 1993.

Latief, Hilman, Melayani Umat: Filantropi Islam dan Ideologi Kesejahteraan Kaum Modernis, Jakarta: Maarif Institut dan Kompas Gramedia, 2010.

Latief, Hilman, Politik Filantropi Islam di Indonesia: Negara, Pasar dan Masyarakat Sipil, Yogyakarta: Ombak, 2013.

Latief, Hilman, Islamic Charities and Social Activism: Welfare Dakwah and Politics in Indonesia, diakses melalui http://www.hilmanlatief.net/2012/09/islamic-charities-and-social-activism-html

Latif, Yudi, Intelegensia Muslim dan Kuasa: Genealogi Intelegensia Muslim Abad 20, Mizan: Bandung, 2005.

Lucas, Anton E., One Soul One Struggle : Peristiwa Tiga Daerah, Yogyakarta: Resist Book, 2004.

Ma'arif, Ahmad Syafi'I, Politik Identitas dan Masa Depan Pluralisme Kita, Jakarta: Democracy Project: Yayasan Abad Demokrasi, 2012.

Madinier, Remy, Partai Masyumi: Antara Godaan Demokratis dan Islam Integral, Bandung: Mizan, 2013.

Mc Chesney, Robert D., Charity and Philanthropy in Islam, diakses melalui http:/ /www.learningtogive.org/faithgroups/phil_in_america/philanthropy_ islam.asp pada 20 november 2013

Midgley, James, Social Welfare in Global Context, London: Sage Publication, 1997. Mitsuo, Nakamura, Bulan Sabit Muncul Dibalik Beringin: Studi tentang Pergerakan Muhammadiyah di Kota Gede, Yogyakarta: Gajah Mada University Press, 1983.

Noer, Deliar, Gerakan Islam Modern di Indonesia: 1990-1942, Jakarta: LP3ES, 1982. 
Pestoff, Victor A., A Democratic Architecture for the Welfare State, New York: Routledge, 2009.

Payton, Robert, Philanthropy: Voluntary Action for The Public Good, New York: American Council on Education, Macmillan, 1988.

Shihab, Alwi, Membendung Arus: Respon Gerakan Muhammadiyah terhadap Penetrasi Misi Kristen di Indonesia, Bandung: Mizan, 1997.

Vandendael, Anoux, et. al., Stimulating Civil Society The Perspective of INGO: an Explorative Study of Indonesia, Erasmus University, 2013.

Widyawati, Filantropi Islam dan Kebijakan Negara Pasca Orde Baru: Studi tentang Undang-Undang Zakat dan Undang-Undang Wakaf, Jakarta: Sekolah Pasca Sarjana UIN Syarif Hidayatullah.

\section{Sumber lain :}

Al Quran

Suara Muhammadiyah. No. 17 Tahun 80/ September 1995

Suara Muhammadiyah No. 07 Tahun 80/ April 1995.

Suara Muhamamdiyah. No. 13 Tahun 85/ Juli 2000

\section{Wawancara:}

Wawancara dengan dr Nurul Chusna, Sekretaris MPKU PWM DIY, pada 17 januari 2014

Wawancara dengan Drs. Muhammad Hatta, Sekretaris PCM Kota Gede, pada 16 Januari 2014

Wawancara dengan Said Tuhuleley, Ketua MPM PP Muhammadiyah pada 16 Januari 2014

Obrolan dengan Ashad Kusumadjaya, Anggota LPCR PP Muhammadiyah pada 11 Januari 2014 